\title{
Komparasi Kemandirian Siswa Berlandaskan Jiwa Entrepreneurship di SMK N 2 Mataram
}

\author{
SAIFUL BAHRI \\ Program Pascasarjana, Universitas Negeri Yogyakarta \\ saifuldbahri@gmail.com
}

\begin{abstract}
Abstrak
Penelitian ini bertujuan mengetahui perbedaan kemandirian siswa yang berlandaskan jiwa entrepreneurship berdasarkan kategori gender, jenis pekerjaan orang tua, jumlah penghasilan dan program keahlian kelas XII di SMK Negeri 2 Mataram. Desain penelitian ini adalah expost facto dengan jenis penelitian komparatif. Data yang diperoleh dianalisis dengan teknik analisis deskriptif dan uji beda. Hasil uji beda kemandirian siswa yang berlandaskan jiwa entrepreneurship menunjukkan bahwa (1) terdapat perbedaan antara siswa laki-laki dan perempuan (P.Sig (2-tailed) $=0,000 \leq \alpha=0,05)$; (2) tidak terdapat perbedaan antara jenis pekerjaan orang tua siswa wiraswasta dan bukan wiraswasta (P.Sig $(2$-tailed $)=0,759 \geq \alpha=0,05)$; (3) tidak terdapat perbedaan antara jumlah penghasilan orang tua siswa 0-2 juta, 2-3 juta, dan $>3$ juta $\left(P\right.$. Sig $_{(2 \text {-tailed })}=0,798 \geq$ $\alpha=0,05)$; (4) terdapat perbedaan antara siswa program keahlian administrasi perkantoran, pemasaran, rekayasa perangkat lunak, dan usaha perjalanan wisata (P.Sig $(2$-tailed $)=0,000 \geq \alpha=0,05)$.
\end{abstract}

Kata kunci: kemandirian, siswa, jiwa entrepreneurship

\begin{abstract}
This research aims to know the difference of students' autonomy based on entrepreneur spirit regarding the category of gender, type of parent's occupation, parents' income, and skill program of grade XII at SMK N 2 Mataram. This research employed exspost-facto design with comparative approach. The collected data were analysed using descriptive analysis techniques and diffetrence testa. The results of the difference tests based on entrepreneur spirit show that (1)there is a difference among female and male students (P.sig $(2$-tailed) $=0.000 \leq \alpha=0.05)$; (2) there isn't a difference regarding the parent's occupation of businessmen and non- businessmen (P.sig(2-tailed) $=0.759 \geq \alpha=0.05)$; (3) parents' income does not have differences (P.sig $(2$-tailed) $=0.798 \geq \alpha=0.05)$; (4) there is a difference of accounting, marketing, software engineering, and tourism skill programs students (P.sig $(2-$ tailed) $=0.000 \leq \alpha=0.05$ ).
\end{abstract}

Keywords: autonomy, student, enterpreneurship spirit 


\section{PENDAHULUAN}

Undang-Undang No. 20 Tahun 2003

Tentang Sistem Pendidikan Nasional

Pasal 3, menyatakan bahwa pendidikan nasional berfungsi mengembangkan kemampuan dan membentuk watak serta peradaban bangsa yang bermartabat dalam rangka mencerdaskan kehidupan bangsa, bertujuan untuk mengembangkan potensi peserta didik agar menjadi manusia yang beriman dan bertakwa kepada Tuhan Yang Maha Esa, berakhlak mulia, sehat, berilmu, cakap, kreatif, mandiri, dan menjadi warga Negara yang demokratis serta bertanggung jawab.

Fungsi dan tujuan di atas, menunjukkan bahwa pendidikan di setiap satuan pendidikan harus diselenggarakan secara sistematis guna mencapai tujuan tersebut. Permasalahannya adalah apakah pendidikan di masing-masing satuan pendidikan telah diselenggarakan dengan baik, dan mencapai hasil seperti yang diharapkan.

Menurut Scott \& Wircenski (1996) sebagaimana dikutip oleh
Rauner (2008:57) mengungkapkan

bahwa:

"A large and diverse educational enterprise, spanning both secondary and postsecondary education. ....[it] encompasses a tremendous number of programs designed to prepare students for employment and for living.

Hal tersebut berarti sebuah lembaga pendidikan yang besar dan beragam, mencakup pendidikan baik menengah dan atas. Meliputi sejumlah besar program yang dirancang untuk mempersiapkan siswa untuk pekerjaan dan untuk hidup. Output dari lembaga pendidikan adalah kemampuan sumber daya manusia untuk memperoleh pekerjaan berdasarkan pengetahuan yang diperoleh pada saat dibangku sekolah.

Selanjutnya deklarasi Bonn UNESCO-UNEVOC pada tanggal 28 Oktober 2004 sebagaimana dikutip oleh Gough (2010:ix), menyatakan bahwa:

"Since education is considered the key to effective development strategies, technical and vocational education and training must be the master key that can alleviate poverty, promote peace, conserve the environment, improve the quality of life for all and 
help achieve sustainable development. (The Bonn Declaration. UNESCOUNEVOC: Bonn, 28 October 2004).

Deklarasi tersebut menegaskan bahwa, karena pendidikan dianggap sebagai kunci untuk strategi pembangunan yang efektif, pendidikan teknik dan kejuruan dan pelatihan harus menjadi kunci master yang dapat mengentaskan kemiskinan, mempromosikan perdamaian, melestarikan lingkungan, meningkatkan kualitas hidup untuk semua dan membantu mencapai pembangunan berkelanjutan. Maka dari itu negaranegara anggota UNESCO menegaskan Deklarasi Bonn dan menyerukan negara-negara anggota UNESCO dan mitra lembaga untuk mengembangkan dan memperluas kemitraan Education for Sustainable Development (ESD) untuk mengintegrasikan ESD ke dalam pelatihan, pendidikan kejuruan dan pembelajaran di tempat kerja dengan melibatkan masyarakat sipil, sektor publik dan swasta, LSM, dan mitra pembangunan. ESD harus menjadi bagian integral dari pelatihan terpimpin dalam bisnis, industri, serikat buruh, non-profit dan organisasi-organisasi sukarela, dan pelayanan publik.

Berkaitan dengan pencapaian tujuan pendidikan nasional terutama yang mengarah pada pembentukan sikap dan perilaku wirausaha sangat penting dilakukan dalam program pemecahan masalah nasional tentang ketenagakerjaan dan pengangguran. Berdasarkan realita, menurut badan pusat statistik (2013: 1), tingkat pengangguran terbuka (TPT) pada Februari tahun 2013 mencapai 5,92 persen, yaitu sebanyak 70.000 orang. Sementara jumlah angkatan kerja di Indonesia pada Februari 2013 mencapai 121,2 juta orang. Menurut Mulia Ginting Munthe sebagaimana yang dikutip oleh Majalah UKM Indonesia Network (2013:18) Untuk mengurangi angka pengangguran, salah satu cara yang bisa dilakukan adalah perlu dikembangkannya karakter kewirausahaan sedini mungkin, karena indikator suatu bangsa akan maju apabila jumlah wirausahanya minimal 2\%, jumlah 
wirausahawan di Singapura ada sebesar 7,2\%, Amerika Serikat $2,14 \%$, Indonesia saat ini telah memiliki 1,56 persen atau sekitar 3.707.205 wirausaha dari jumlah populasi penduduk Indonesia.

Data di lapangan menunjukan bahwa jumlah pengangguran terdidik masih tinggi. Adapun data pengangguran dari BPS disajikan pada :

Tabel 1. Tingkat Pengangguran Terbuka (TPT) Menurut Penidikan tertinggi yang Ditamatkan

\begin{tabular}{|c|c|c|c|c|}
\hline \multirow{2}{*}{$\begin{array}{c}\text { Pendidikan } \\
\text { tertinggi } \\
\text { yang } \\
\text { ditamatkan }\end{array}$} & \multicolumn{2}{|c|}{2011} & \multicolumn{2}{|c|}{2012} \\
\hline & Feb & Agust & Feb & Agust \\
\hline$<\mathrm{SD}$ & 3,37 & 3,56 & 3,69 & 3,64 \\
\hline SMP & 7,83 & 8,37 & 7,80 & 7,75 \\
\hline SMA & 12,17 & 10,66 & 10,34 & 9,60 \\
\hline SMK & 10,00 & 10,43 & 9,51 & 9,87 \\
\hline $\begin{array}{l}\text { Diploma } \\
\text { I/II/III }\end{array}$ & 11,59 & 7,16 & 7,50 & 6,21 \\
\hline $\begin{array}{l}\text { Univer- } \\
\text { Sitas }\end{array}$ & 9,95 & 8,02 & 6,95 & 5,91 \\
\hline Jumlah & 6,80 & 6,56 & 6,32 & 6,41 \\
\hline
\end{tabular}

Sumber: BPS Kota Mataram tahun 2012

Data di atas menunjukan bahwa jumlah pengangguran lulusan SMK masih tinggi yaitu dilihat pada bulan Febuari 2011 terdapat 10,43\% bulan Agustus 2010 terdapat 11,87\% bulan Febuari 2011 terdapat 10,00\% dan pada bulan Agustus 2011 terdapat 10,43. Data tersebut apabila dibandingkan dengan tamatan
Sekolah Dasar (SD) dan Sekolah Menengah Pertama (SMP) ternyata memiliki persentase yang lebih tinggi. Seperti halnya tingkat pengangguran di kota Mataram jumlah pengangguran mencapai $6,53 \%$ orang dari 69,38 Jumlah penduduk usia kerja (BPS,2012). Pengangguran tersebut terjadi karena kebanyakan orang masih mengharapkan kerja pada instansi yang tidak memiliki resiko tinggi seperti Pegawai Negeri Sipil (PNS) maupun instansi yang mampu memberikan gaji setiap bulannya, sedangkan untuk pekerjaan yang memiliki resiko tinggi seperti berwirausaha mereka kurang tertarik.

Berdasarkan kenyataan yang ada, pendidikan kewirausahaan di Indonesia masih perlu ditingkatkan, guna menciptakan progres yang positif, baik oleh dunia pendidikan maupun masyarakat. Pendidik masih kurang memperhatikan penumbuhan karakter dan perilaku wirausaha peserta didik, baik di sekolah-sekolah kejuruan, maupun di sekolah menengah umum. Sekolah 
menengah, pada umumnya hanya fokus menyiapkan calon tenaga kerja. Untuk itu, perlu dicari jalan keluarnya agar pendidikan dapat berperan untuk mengubah generasi muda yang memiliki karakter dan keterampilan wirausaha. Untuk mencapai tujuan tersebut bekal apa yang perlu diberikan kepada peserta didik agar memiliki karakter dan atau perilaku wirausaha yang tangguh, sehingga diharapakan akan tumbuh generasi penerus bangsa yang inovatif, gigih, tekun, ulet dalam segala bidang keilmuan yang ditekuninya.

Kota Mataram sebagai ibukota provinsi Nusa Tenggara Barat (NTB) merupakan pusat berbagai aktifitas seperti pusat pemerintahan, pendidikan, perdagangan, industri dan jasa, saat ini tengah dikembangkan untuk menjadi kota pariwisata. Keberadaan berbagai fasilitas penunjang seperti fasilitas perhubungan seperti Bandara Internasional Selaparang sebagai pintu masuk Lombok melalui udara, pusat perbelanjaan, dan jalur transportasi yang menghubungkan antar kabupaten dan propinsi inilah yang menjadi pertimbangan dalam pengembangan Kota Mataram menjadi kota pariwisata (BPS kota Mataram, 2012:2).

Tabel 2. Persentase Penduduk Kota Mataram yang Bekerja Menurut Status Pekerjaan

\begin{tabular}{|c|c|c|c|}
\hline $\begin{array}{c}\text { Status } \\
\text { pekerjaan }\end{array}$ & $\begin{array}{l}\text { Laki- } \\
\text { laki } \\
(\%)\end{array}$ & $\begin{array}{c}\text { Perem } \\
\text { puan } \\
(\%)\end{array}$ & $\begin{array}{c}\text { Laki- } \\
\text { laki } \\
\text { dan } \\
\text { Perem } \\
\text { puan } \\
(\%)\end{array}$ \\
\hline Berwirausaha & 33.50 & 45.35 & 37.96 \\
\hline $\begin{array}{l}\text { Buruh/karya } \\
\text { wan }\end{array}$ & 49.54 & 38.46 & 45.37 \\
\hline Pekerja bebas & 14.25 & 3.40 & 10.16 \\
\hline $\begin{array}{l}\text { Pekerja } \\
\text { keluarga }\end{array}$ & 2.71 & 12.79 & 6.51 \\
\hline Total & $\begin{array}{r}100.0 \\
0\end{array}$ & 100.00 & $\begin{array}{r}100.0 \\
0\end{array}$ \\
\hline
\end{tabular}

Sumber : BPS Kota Mataram tahun 2011

Selanjutnya berikut proyeksi data kondisi masyarakat Penduduk miskin di kota Mataram tahun 20072011.

Tabel 3. Penduduk Miskin di Kota Mataram Tahun 2007-2011

\begin{tabular}{cccccc}
\hline Kemiski & 200 & 200 & 200 & 201 & 201 \\
nan & 7 & 8 & 9 & 0 & 1 \\
\hline $\begin{array}{c}\text { Pendudu } \\
\text { k miskin }\end{array}$ & 9,6 & 16, & 15, & 14, & 13, \\
$(\%)$ & 7 & 13 & 41 & 44 & 38 \\
\hline Jumlah & & & & & \\
pendudu & 35, & 61, & 60, & 58, & 53 \\
k miskin & 91 & 17 & 63 & 27 & 73 \\
\hline
\end{tabular}
(\%)

Sumber : BPS Kota Mataram tahun 2012 
Dalam konteks pembangunan manusia masalah kemiskinan dapat menjadi akar dari permasalahan sosial dalam suatu daerah. Kota Mataram dengan kepadatan penduduk yang cukup tinggi rawan akan hal ini.

SMK sebagai lembaga pendidikan yang menghasilkan lulusan siap kerja adalah salah satu bentuk kebijakan pemerintah untuk menanggulangi pengangguran, yang terkoordinasi di dalamnya adalah kementrian pendidikan dan kementrian koperasi dan UKM. Proses pendidikan di SMK mengacu pada pelatihan dan pelaksanaan praktis dari berbagai jenis jurusan yang disediakan.

Kesiapan dalam kemandirian berwirausaha didukung oleh banyak faktor. Beberapa diantaranya yaitu pertama berkaitan dengan gender, Jenis kelamin juga mempengaruhi dalam minat berwirausaha seseorang dan sering menyebabkan perbedaan seseorang dalam hal jiwa kewirausahaan. Hal tersebut disebabkan adanya karakteristik yang melekat pada klasifikasi gender tersebut. Laki-laki, misalnya pada umumnya lebih dominan dalam menggunakan rasio dalam cara berpikir, bertindak, dan bersikap terhadap suatu objek. Hal ini berarti ciri-ciri dominan pada seorang wirausaha seperti yang dikemukakan oleh Meredith (2002) lebih dimiliki oleh laki-laki daripada perempuan. Dengan demikian diduga kuat bahwa antara siswa lakilaki dan siswa perempuan berbeda dalam hal jiwa kewirausahaan dan minat berwirausahanya (Mubadi \& Laurentius Saptono, 2005:20).

Selain gender, faktor lain yang memiliki peran dalam memandirikan siswa yang berlandaskan jiwa entrepreneurship adalah jenis pekerjaan orang tua. Peran keluarga juga sangat penting dalam menumbuhkan minat berwirausaha bagi para siswa. Pendidikan berwirausaha dapat berlangsung sejak usia dini dalam lingkungan keluarga.

Having a mother or father who is selfemployed provides a strong inspiration for the entrepreneur. The independent nature and flexibility of self-employment is ingrained at an early age" (Hisrich et al., 2008:65). 
Memiliki seorang ibu dan ayah yang berwirausaha memberikan inspirasi kepada anak untuk menjadi wirausahawan. Fleksibilitas dan kemandirian dari wirausahawan telah mendarah daging pada anak sejak dini. Anak terinspirasi untuk berwirausaha karena melihat kesungguhan dan kerja keras ayah dan ibunya atau orangtuanya berusaha dengan kegigihan yang menghasilkan keuntungan. Anak juga terinspirasi karena memang dilatih sejak kecil, diminta membantu mulai dari pekerjaan yang ringan atau mudah sampai yang rumit dan komplek. Terlatih dan terinspirasi sehingga mempengaruhi minatnya dalam berwirausaha.

Jumlah penghasilan orang tua juga memiliki peran dalam menumbuhkan kemandirian siswa yang berlandaskan jiwa entrepreneurship, hal ini diungkapkan oleh Susanto (2007: 17) bahwa

"Banyak wirausahawan yang pada mulanya terutama pada masa kecilnya, adalah orang-orang yang hanya memiliki sedikit uang serta pendidikan yang relatif tidak terlalu tinggi, justru tantangan yang dihadapi sejak masa kecil inilah yang turut berkonstribusi bagi terbentuknya jiwa kewirausahaan seseorang".

Berdasarkan teori tersebut, latar belakang ekonomi keluarga siswa yang melanjutkan ke SMK adalah rendah. Hal ini karena adanya dorongan dari orang tua dan persepsi awal masyarakat umum bahwa jika melanjutkan pendidikan ke SMK akan dapat bekerja segera setelah lulus. Sementara siswa yang memiliki latar belakang ekonomi yang cenderung baik lebih memilih untuk melanjutkan pendidikan ke SMA karena sudah cenderung untuk melanjutkan pendidikan ke perguruan tinggi.

Pada pedidikan di SMK kewirausahaan telah terstruktur di dalam kurikulum sejak tahun 1999. Bahkan Kementerian Pendidikan Nasional melalui Direktorat Pendidikan Menengah Kejuruan meluncurkan suatu program khusus yaitu Program kelas wirausaha (Munzirnet, 2010). Program in dikembangkan di SMK sesuai dengan program keahliannya masingmasing. Sehingga masing-masing sekolah dapat memilih program 
keahlian yang menjadi unggulan yang paling memungkinkan untuk mengembangkan potensi wirausaha pada siswa.

Penekanan utama program kelas wirausaha (entrepreneurship) ini adalah pada proses membangun dan mengambangkan jiwa wirausaha dimana didalamnya para siswa kelas III SMK belajar menekuni suatu jenis usaha dengan mengelola usaha sendiri, mengatasi masalah, menemukan kiat-kiat dalam usaha meraih sukses secara kompetitif. Dalam program ini siswa didorong untuk berani melihat peluang usaha, merancang dan mencoba sesuatu jenis usaha yang ingin dibangunnya. Untuk mereaisasikan gagasannya dalam membangun bidang usaha.

Mengacu dari hal tersebut, sehingga dikatakan program keahlian memiliki peran terhadap kemantapan kemandirian siswa yang berlandaskan jiwa entrepreneurship di SMK. SMK Negeri 2 Mataram sendiri memiliki 5 (lima) program keahlian, yakni aadministrasi perkantoran (AP), akuntansi (AKT), pemasaran (PMS), rekayasa perangkat lunak (RPL), serta usaha perjalanan wisata (UPW).

Uraian di atas mengemukakan bahwa kemantapan lulusan SMK untuk mandiri berwirausaha dapat dipengaruhi oleh beberapa faktor internal maupun eksternal pada siswa, yaitu karakter kemandirian yang dimiliki. Faktor inklusif dari kemandirian siswa yang berlandaskan jiwa entrepreneurship, yakni gender, jenis pekerjaan orang tua, jumlah penghasilan orang tua, dan program keahlian yang dapat diidentifikasi dan diukur pada siswa SMK Negeri 2 mataram.

\section{METODE}

Desain penelitian ini adalah expost facto karena data diambil apa adanya tanpa ada perlakuan, dengan jenis penelitian komparatif. Penelitian dilaksanakan di Sekolah Menengah Kejuruan Negeri 2 Mataram. Pengambilan sampel menggunakan teknik cluster sampling. Penentuan jumlah sampel menggunakan teknik yang dikembangkan oleh Issac dan Michael. Variabel pada penelitian ini adalah kemandirian siswa yang 
berlandaskan jiwa entrepreneurship, dengan penilaian berdasarkan kategori gender, jenis pekerjaan orang tua, jumlah penghasilan orang tua, dan program keahlian.

Pengumpulan data dalam penelitian ini menggunakan kuesioner dan dokumentasi. Menggunakan Instrumen berupa angket atau kuesioner. Teknik analisis data menggunakan statistik deskriptif dan Uji beda. Data disajikan dalam bentuk tabel dan histogram.

\section{HASIL DAN PEMBAHASAN}

Data tentang kemandirian siswa yang berlandaskan jiwa entrepreneurship yang terkumpul kemudian dikelompokkan menjadi empat kategori sebagai berikut:

Tabel 4. Interval Skor dan Kriteria Untuk Setiap Kategori Kemandirian Siswa yang Berlandaskan Jiwa Entrepreneurship Interval Skor dan Kriteria

\begin{tabular}{cc}
\hline Interval Skor & Kriteria \\
\hline $97-120$ & Sangat tinggi \\
\hline $74-97$ & Tinggi \\
\hline $52-74$ & Rendah \\
\hline $30-52$ & Sangat rendah \\
\hline
\end{tabular}

Pertama, menunjukkan bahwa kemandirian siswa yang berlandaskan jiwa entrepreneurship untuk kategori gender laki-laki dan perempuan keduanya masuk dalam kriteria rendah.

Kategori gender kelas XII SMK Negeri 2 Mataram dapat juga dilihat dalam bentuk Diagram batang berikut:

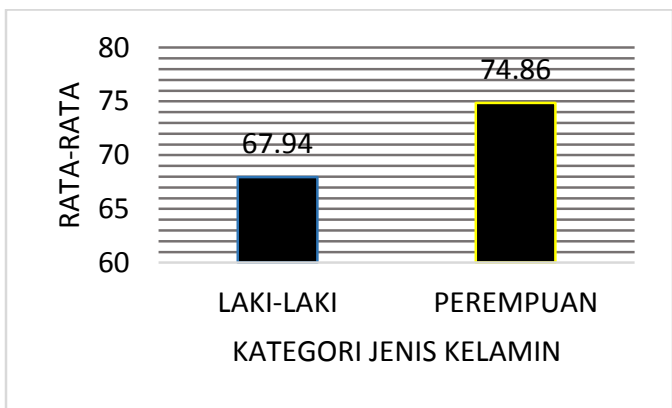

Gambar 1. Diagram Batang Skor Rata-Rata Kemandirian Siswa yang Berlandaskan Jiwa Entrepreneurship Berdasarkan Gender

Berdasarkan diagram tersebut terlihat adanya kenyataan bahwa walaupun dalam satu sekolah antar siswa laki-laki dan perempuan kemandirian siswa yang berlandaskan jiwa entrepreneurship memiliki tingkat yang berbeda walaupun masih dalam trend rendah, sehingga dapat menjadi bahan pertimbangan guru dalam mengajar untuk menggunakan metode yang kreatif agar secara bersama-sama 
tumbuh kemandirian siswa yang belakang pekerjaan orang tua siswa berlandaskan jiwa entrepreneurship tidak menyumbangkan kemandirian antara siswa laki-laki dan yang berlandaskan jiwa perempuan.

entrepreneurship bagi siswa,

Kedua, kemandirian siswa yang sehingga daripada itu sekolah berlandaskan jiwa entrepreneurship memiliki tanggung jawab dalam berdasarkan jenis pekerjaan orang meningkatkan kemandirian siswa tua diketahui masuk dalam kriteria yang berlandaskan jiwa rendah. Kategori jenis pekerjaan entrepreneurship tersebut melalui orang tua kelas XII SMK Negeri 2 penyelenggaraan program-program Mataram dapat juga dilihat dalam khusus.

bentuk Diagram batang berikut:

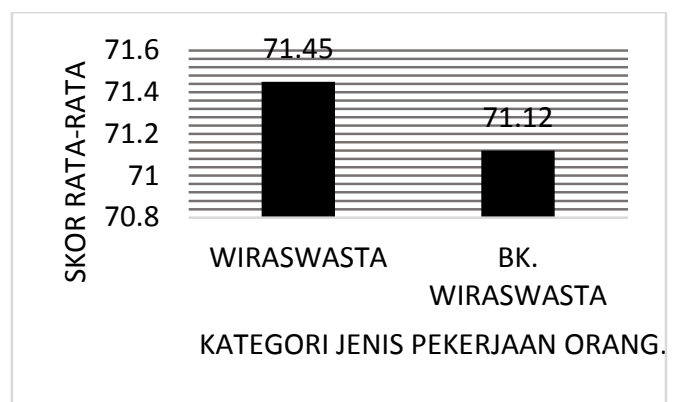

Gambar 2. Diagram Batang Skor Rata-Rata Kemandirian Siswa yang Berlandaskan Jiwa Entrepreneurship Berdasarkan Jenis Pekerjaan Oramg Tua

Berdasarkan diagram 2 tersebut terlihat bahwa tingkat kemandirian siswa yang berlandaskan jiwa entrepreneurship tidak terpaut berbeda walaupun masih dalam trend rendah, sehingga dapat menjadi bahan pertimbangan sekolah bahwa apapun latar
Ketiga, kemandirian siswa yang berlandaskan jiwa entrepreneurship berdasarkan jumlah penghasilan orang tua diketahui bahwa nilai ratarata untuk siswa dengan jumlah penghasilan orang tua $0-2$ juta sebesar 71,37, 2-3 juta sebesar 70,75 dan >3 juta sebesar 72,04, berdasarkan pada tabel 3 menunjukkan bahwa kemandirian siswa yang berlandaskan jiwa entrepreneurship untuk kategori jumlah penghasilan orang tua keduanya masuk dalam kriteria rendah.

Kategori jenis pekerjaan orang tua kelas XII SMK Negeri 2 Mataram dapat juga dilihat dalam bentuk Diagram batang berikut: 


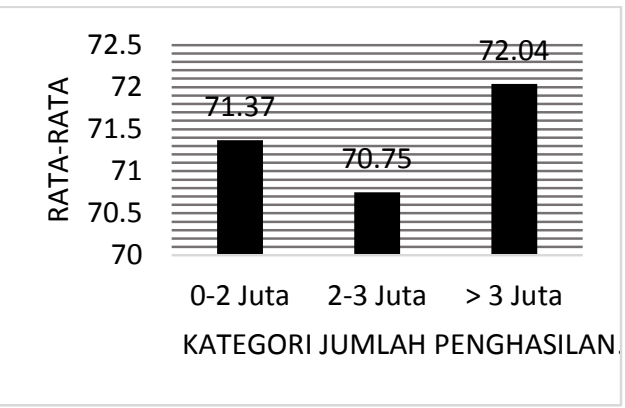

Gambar 3. Diagram Batang Skor Rata-Rata Kemandirian Siswa yang Berlandaskan Jiwa Entrepreneurship

Berdasarkan Jumlah Penghasilan Orang Tua

Berdasarkan diagram 3 terlihat bahwa tingkat kemandirian siswa yang berlandaskan jiwa entrepreneurship tidak terpaut berbeda. Dan ketiganya masih dalam trend rendah, sehingga pihak sekolah dapat meningkatkan kemandirian siswa yang berlandaskan jiwa entrepreneurship menjadi lebih signifikan melalui pemanfaatan business center $(B C)$ yang tersedia, karena melalui pembelajaran kewirausahaan yang aktif akan membelajarkan siswanya untuk dapat langsung merasakan keuntungan dari berwirausaha.

Keempat, kemandirian siswa yang berlandaskan jiwa entrepreneurship berdasarkan program keahlian diketahui bahwa nilai rata-rata untuk siswa dengan program keahlian akuntansi masuk dalam kriteria rendah $(71,48)$, pemasaran masuk dalam kriteria rendah $(68,94)$, rekayasa perangkat lunak masuk dalam kriteria rendah $(69,50)$, usaha perjalanan wisata masuk dalam kriteria rendah $(69,50), \quad$ dan administrasi perkantoran masuk dalam kriteria tinggi $(76,34)$.

Kategori program keahlian kelas XII SMK Negeri 2 Mataram dapat juga dilihat dalam bentuk Diagram batang berikut:

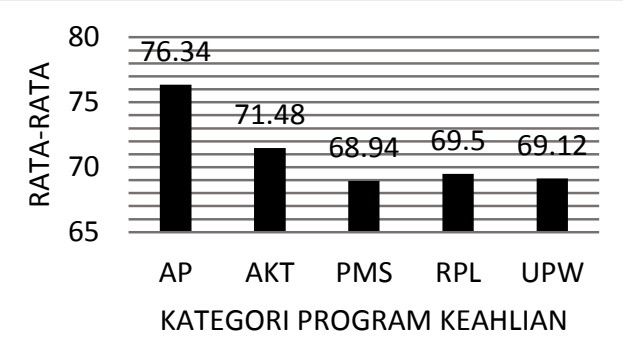

Gambar 4. Diagram Batang Skor Rata-Rata Kemandirian Siswa yang Berlandaskan Jiwa Entrepreneurship Berdasarkan Program Keahlian

Berdasarkan diagram 4 tersebut terlihat bahwa tingkat kemandirian siswa yang berlandaskan jiwa entrepreneurship kategori program keahlian masuk dalam kriteria rendah, kecuali program keahlian 
administrasi perkantoran. Hal ini menjadi pedoman untuk sekolah agar membenahi pembelajaran kewirausahaan disekolah, karena dari lima program keahlian yang ada, hanya satu program keahlian yang memiliki tingkat kemandirian yang berlandaskan jiwa entrepreneurship yang tinggi, guna menjadikan SMK Negeri 2 Mataram yang memiliki kualitas output siswa yang baik, maka harus dilakukan penanganan maksimal untuk meningkatkan kemandirian siswa yang berlandaskan jiwa entrepreneurship.

\section{Komparasi Kemandirian Siswa} yang Berlandaskan Jiwa Entrepreneurship Berdasarkan

\section{Gender}

Terdapat perbedaan kemandirian siswa yang berlandaskan jiwa entrepreneurship secara signifikan antara siswa laki-laki dan perempuan di SMK Negeri 2 Mataram.

Hal ini dibuktikan dengan berdasarkan hasil analisa komparasi kemandirian siswa yang berlandaskan jiwa entrepreneurship melalui uji independent sample t-tes antara laki-laki dan perempuan menunjukkan nilai probability signifikansi sebesar 0,000, atau lebih kecil dari koefisien $\alpha=0,05$.

Hasil ini didukung oleh hasil penelitian yang dilakukan oleh Hoogendoorn, Oosterbeek \& Praag (2013) yang berjudul The impact of Gender Diversity on The Performance of Business Team.

Dalam penelitian ini mengungkapkan bahwa "Gender mix perform better than individual team of sales and profits". Hal tersebut berarti campuran jenis kelamin, berperforma lebih baik dibandingkan tim individu jenis kelamin terpisah pada penjualan dan keuntungan. Walaupun memang dikelas antara siswa laki-laki dan perempuan sama-sama belajar kewirausahaan tetapi secara penerimaan pembelajaran masih bersifat masing-masing, karena tidak melibatkan keduanya dalam pembelajaran praktis kewirausahaan seperti menjual produk.

Berdasarkan data tersebut juga mengindikasikan bahwa kategori 
jenis kelamin perempuan lebih tinggi kemandirian yang berlandaskan jiwa entrepreneurship

dibandingkan dengan laki-laki, hal ini sesuai dengan data yang rilis oleh BPS kota Mataram tahun 2011, tentang persentase penduduk yang bekerja menurut status pekerjaan, dimana laki-laki hanya menunjukkan persentase sebanyak 33,50, sedangkan untuk perempuan jumlah persentase sebanyak 45,35. Dalam kurun waktu 3 tahun sampai dengan saat ini (2014), trend tersebut masih berlaku hal ini mengindikasikan lakilaki lebih menginginkan menjadi buruh/karyawan daripada berusaha sendiri (berwirausaha).

Selain itu secara praktis siswa perempuan di sekolah maupun diluar sekolah lebih aktif daripada siswa laki-laki dalam hal mencari uang saku tambahan, di sekolah sendiri siswa perempuan banyak yang berjualan pulsa elektrik, assesoris, kue hingga berjualan pakaian online, walaupun masih dalam skala kecil namun hal tersebut bisa menumbuhkan kemandirian siswa perempuan daripada siswa laki-laki.

Dari pembahasan diatas, diharapkan guru dapat memberikan pembelajarn yang tepat sasaran serta efektif guna menggali kemandirian siswa yang berlandaskan jiwa entrepreneurship yang nantinya dapat dikembangkan menjadi sikap wirausaha, sehingga dapat memunculkan semangat usaha, menciptakan peluang bisnis, atau mengembangkan produk yang ada dengan inovasi yang lebih berdaya guna oleh siswa maupun siswi SMK.

Komparasi Kemandirian Siswa yang Berlandaskan Jiwa Entrepreneurship Berdasarkan Jenis Pekerjaan Orang Tua

Tidak terdapat perbedaan kemandirian siswa yang berlandaskan jiwa entrepreneurship secara signifikan antara siswa dengan pekerjaan orang tua wiraswasta dan bukan wiraswasta di SMK Negeri 2 Mataram.

Hal ini di ditunjukkan dengan nilai probability signifikansi sebesar 
0,759, atau lebih besar dari koefisien $\alpha=0,05$. Dengan hasil perhitungan ini menunjukkan bahwa meskipun siswa berbeda dalam hal latar belakang pekerjaan orang tua masing-masing, namun tingkat kemandirian siswa yang berlandaskan jiwa entrepreneurship yang ada pada diri masing-masing siswa tersebut tidak jauh berbeda antarkelompok. Dengan kata lain, pembelajaran kewirausahaan yang siswa dapati di sekolah serta dengan asumsi bahwa siswa dengan latar belakang pekerjaan orang tua bisa membantu menumbuhkembangkan kemandirian secara umum tidak berdampak pada tingginya kemandirian siswa yang berlandaskan jiwa entrepreneurship yang terbentuk.

\section{Hasil} penelitian mengindikasikan bahwa kemadirian siswa untuk berwirausaha masih rendah, terlepas dari background orang tua yang memiliki peran dalam kemandirian anak-anak mereka, disini peneliti melihat tingkat kemandirian siswa yang berlandaskan jiwa entrepreneurship yang terbentuk akibat dari setelah melakukan pembelajaran kewirausahaan itu sendiri. Berdasarkan data BPS kota Mataram yang dirilis tahun 2011 tentang tentang persentase penduduk yang bekerja menurut status pekerjaan, jumlah penduduk kota Mataram yang berstatus sebagai wirausahawan sebanyak 37.96 persen, sedangkan penduduk kota mataram yang berstatus bukan wirausahawan baik itu sebagai buruh/karyawan, pekerja bebas, dan pekerja keluarga berjumlah 62.04 persen, ini mengindikasikan jumlah pekerja dikota mataram didominasi oleh masyarakat dengan jenis pekerjaan bukan wiraswasta, hal tersebut membuktikan bahwa untuk mempengaruhi anak-anak oleh orang tuanya diyakini tidak mungkin karena pekerjaan bukan wirausaha. Wirausaha tidak mendapat porsi yang banyak dihati masyarakat kota Mataram. Selain itu di masyarakat masih membudaya pola pikir bahwa bekerja itu identik dengan menjadi pegawai, jadi belum menjadi pegawai berarti belum bekerja 
walaupun sebenarnya seseorang belakang Jumlah Penghasilan Orang tersebut memiliki usaha yang bisa tua masing-masing, namun tingkat menjadi sumber pendapatannya. kemandirian siswa yang Selama budaya seperti ini terus berlandaskan jiwa entrepreneurship berkembang maka generasi ke yang ada pada diri masing-masing generasi tidak mendapatkan siswa tersebut tidak jauh berbeda peningkatan kemampuan untuk antar kategori. Dengan kata lain, mandiri menjadi wirausahawan pembelajaran kewirausahaan yang siswa dapati di sekolah serta dengan Komparasi Kemandirian Siswa asumsi bahwa siswa dengan latar yang Berlandaskan Jiwa belakang Jumlah Penghasilan Orang Entrepreneurship Berdasarkan tua bisa membantu Jumlah Penghasilan Orang Tua menumbuhkembangkan

Tidak terdapat perbedaan kemandirian secara umum tidak kemandirian siswa yang berdampak pada tingginya berlandaskan jiwa entrepreneurship kemandirian siswa yang secara signifikan antara siswa berlandaskan jiwa entrepreneurship dengan penghasilan orang tua 0-2 yang terbentuk.

Juta, 2-3 Juta dan >3 Juta di SMK

Keadaan dimana tingkat Negeri 2 Mataram.

kemandirian siswa rendah tidak

Hasil ini ditunjukkan nilai memiliki beda nyata pada masingprobability signifikansi sebesar masing tingkatan Jumlah 0,798, atau lebih besar dari koefisien Penghasilan Orang tua disebabkan $\alpha=0,05$, dengan hasil penghitungan dengan alasan bahwa rata-rata bahwa tidak terdapat perbedaan sumber mata pencaharian orang tua antara masing-masing kategori adalah pegawai, dan kalaupun Jumlah Penghasilan Orang Tua. menjadi wirausahawan Dengan hasil perhitungan ini penghasilannya belum mampu menunjukkan bahwa meskipun menaikkan kesejahteraan keluarga, siswa berbeda dalam hal latar sehingga terbentuk suatu mindset 
bahwa anak-anak harus lebih dari signifikansi sebesar 0,000, atau lebih keadaan orang tuanya saat ini, kecil dari koefisien $\alpha=0,05$, dengan sehingga orang tua tidak hasil penghitungan terdapat mengajarkan atau membimbing perbedaan antara program keahlian, anak-anak mereka menjadi yakni program keahlian administrasi wirausahawan, karena yang paling perkantoran (AP) dengan program penting adalah anak-anak mereka keahlian pemasaran (PMS), rekayasa kelak agar menjadi pegawai, tidak perangkat lunak (RPL), usaha berusaha layaknya orang tua mereka perjalanan wisata (UPW). Dengan saat ini. hasil perhitungan ini menunjukkan bahwa hanya program keahlian yang

Komparasi Kemandirian Siswa memiliki perbedaan dengan program yang Berlandaskan Jiwa keahlian lainnya, meskipun terdapat Entrepreneurship Berdasarkan lima program keahlian di SMK Program Keahlian Negeri 2 Mataram namun hanya Terdapat perbedaan kemandirian terdapat satu program keahlian yang siswa yang berlandaskan jiwa berbeda dengan program keahlian entrepreneurship secara signifikan yang lainnya, yakni administrasi antara siswa program keahlian perkantoran (AP), ini berarti tingkat administrasi perkantoran (AP) kemandirian siswa yang terhadap pemasaran (PMS), berlandaskan jiwa entrepreneurship rekayasa perangkat lunak (RPL), dan yang ada pada kategori program usaha perjalanan wisata (UPW) di keahlian administrasi perkantoran SMK Negeri 2 Mataram.

Hal ini di tunjukkan dengan (AP) pada masing-masing siswa tersebut berbeda antar kategori. hasil program keahlian akuntansi, Dengan kata lain, pembelajaran administrasi perkantoran, kewirausahaan yang siswa dapati pemasaran, rekayasa perangkat pada kategori program keahlian lunak, dan usaha perjalanan wisata administrasi perkantoran (AP) bisa menunjukkan nilai probability membantu menumbuhkembangkan 
kemandirian secara umum tidak tinggi) daripada program keahlian berdampak pada tingginya yang lainnya.

kemandirian siswa yang Hal ini sesuai dengan hasil berlandaskan jiwa entrepreneurship penelitian yang dilakukan oleh Jang yang terbentuk.

Penyelenggaraan program (2013) dengan judul penelitian: keahlian administrasi perkantoran yang besar di SMK Negeri 2 Mataram masih menggunakan paradigma lama hubungan pendidikan dan ketenagakerjaan dan manpower requirement approach. Akibatnya penyelenggaraan program keahlian administrasi perkantoran gagal memenuhi tuntutan efisiensi Modeling student entrepreneurship: a longitudinal study, yang menyatakan: "there are other options to practice entrepreneurship, such as starting as joiners of an existing venture as an employee". Jang mengungkapkan bahwa ada pilihan lain untuk berlatih kewirausahaan, seperti memulai sebagai joiner dari usaha yang ada sebagai karyawan.

pendidikan kejuruan/vokasi. Suplay tenaga kerja administrasi

\section{SIMPULAN}

perkantoran tidak seimbang dengan

Terdapat perbedaan kemandirian demand dunia kerja administrasi siswa yang berlandaskan jiwa perkantoran. Sehingga banyak entrepreneurship secara signifikan lulusan program keahlian antara siswa laki-laki dan administrasi perkantoran tidak perempuan di SMK Negeri 2 tertampung di dunia kerja.

Sementara lulusan jurusan ini Mataram. Kesimpulan ini diperoleh melalui perbedaan skor rata-rata memiliki etos yang baik dalam bekerja, sehingga dengan keadaan kemandirian siswa laki-laki sebesar seperti itu banyak lulusan 67,94 dan siswa perempuan sebesar administrasi perkantoran yan 74,86. Berdasarkan hasil uji menjadi wirausawan, sehingga nilai Thitung sebesar -7,362 kemandiriannya berbeda (lebih 
signifikansi(2-tailed) 0,000 menyatakan bahwa lebih kecil dari $\alpha=0,05$.

Tidak terdapat perbedaan kemandirian siswa yang berlandaskan jiwa entrepreneurship secara signifikan antara siswa dengan pekerjaan orang tua wiraswasta dan bukan wiraswasta di SMK Negeri 2 Mataram atau dengan kata lain hipotesis awal ditolak. Kesimpulan ini diperoleh melalui perbedaan skor rata-rata kemandirian siswa dengan orang tua wiraswasta sebesar 71,45 dan bukan wiraswasta $\quad$ sebesar $\quad 71.12$. Berdasarkan hasil uji independent sample t-tes diperoleh nilai $\mathrm{T}_{\text {hitung }}$ sebesar 0,307 lebih kecil dari $\mathrm{T}_{\text {tabel }}$ sebesar 1,960, serta dengan signifikansi(2-tailed) 0,759 menyatakan bahwa lebih besar dari $\alpha=0,05$.

Tidak terdapat perbedaan kemandirian siswa yang berlandaskan jiwa entrepreneurship secara signifikan antara siswa dengan penghasilan orang tua 0-2 Juta, 2-3 Juta dan >3 Juta di SMK Negeri 2 Mataram atau dengan kata lain hipotesis awal ditolak. Kesimpulan ini diperoleh melalui diperoleh nilai $F_{h i t u n g}$ sebesar 8,553 perbedaan skor rata-rata kemandirian siswa dengan orang tua berpenghasilan 0-2 Juta sebesar $71,37,2-3$ Juta sebesar 70,73 dan $>3$ Juta sebesar 72,04. Berdasarkan hasil uji anova one-way diperoleh nilai $\mathrm{F}_{\text {hitung }}$ sebesar 0,226 lebih kecil dari $F_{\text {tabel }}$ sebesar 3,04, serta dengan signifikansi $\quad 0,798$ menyatakan bahwa lebih besar dari $\alpha=0,05$.

Terdapat perbedaan kemandirian siswa yang berlandaskan jiwa entrepreneurship secara signifikan antara siswa program keahlian administrasi perkantoran (AP) terhadap pemasaran (PMS), rekayasa perangkat lunak (RPL), dan usaha perjalanan wisata (UPW) di SMK Negeri 2 Mataram. Kesimpulan ini diperoleh melalui perbedaan skor rata-rata kemandirian siswa kompetensi keahlian administrasi perkantoran (AP) sebesar 76,34, pemasaran (PMS) sebesar 68,94, rekayasa perangkat lunak (RPL) sebesar 69,50 dan usaha perjalanan wisata (UPW) sebesar 69,12. Berdasarkan hasil uji anova one-way 
lebih besar dari $F_{\text {tabel }}$ 2,41, serta Hoogendoorn, S., Oosterbeek, H., \& dengan signifikansi 0,000 menyatakan bahwa lebih kecil dari $\alpha=0,05$.

\section{UCAPAN TERIMA KASIH}

Kami ucapkan terima kasih kepada semua pihak yang mendukung penelitian ini. Selanjutnya kepada redaksi yang memuat artikel ini sehingga hasil penelitian dapat dijadikan salah satu sumber informasi bagi perkembangan ilmu pengetahuan.

\section{DAFTAR PUSTAKA}

BPS Kota Mataram. 2012. Mataram dalam angka:2012. Mataram: BPS Kota Mataram.

BPS Kota Mataram. 2012. Profil kabupaten/kota: kota Mataram. NTB. BPS Kota Mataram.

Gough, S. 2010. Technical and vocational education and training: an investment-based approach. London: Continuum.

Hisrich, R. D, Peters, M. P, \& Shepheid, D. A. 2008. Entrepreneurship (International ed.). New York: MC.Graw Hill.

Praag, M.V. 2013. The impact of gender diversity on the performance of business team: evidence from a field experiment. Management Science, 59, 1514-1528.

Jang, Y. 2013. Modeling student entrepreneurship: a longitudinal study. Journal of entrepreneurship education, 16, 93-114.

Mubadi \& Saptono, Laurentius. 2005. Jiwa kewirausahaan siswa SMK: Suatu Survei Pada 3 SMK Negeri dan 7 SMK Swasta di DIY. Jurnal Penelitian Widya Dharma. Vol 16, No. 1. 15-28.

Munzirnet. 2010. Pendidikan kewirausahaan (entrepreneurship) menanamkan jiwa kemandirian siswa. Diambil pada tanggal 12 Agustus 2013, dari http://munzirnet.blogspot.co $\mathrm{m} / 2010 / 06 /$ pendidikankewirausahaan.html.

Rauner, F. 2008. Handbook of technical and vocational education and training research. Germany: Springer.

Susanto, A.B. 2007. Leaderpreneurship pendekatan management strategik kewirausahaan. Jakarta: Erlangga. 